\title{
A comparison of purebred Holstein-Friesian and Holstein-Friesian $\times$ beef breed bulls for beef production and carcass traits
}

\author{
Arto Huuskonen ${ }^{1 *}$, Maiju Pesonen ${ }^{1}$, Hilkka Kämäräinen ${ }^{2}$ and Risto Kauppinen ${ }^{2}$ \\ ${ }^{1}$ MTT Agrifood Research Finland, Animal Production Research, Fl-92400 Ruukki, Finland \\ ${ }^{2}$ Savonia University of Applied Sciences, P O Box 72, FI-74101 lisalmi, Finland \\ email: arto.huuskonen@mtt.fi
}

\begin{abstract}
The objective of this study was to determine beef production traits of purebred Holstein-Friesian ( $\mathrm{Hol}$ ) and Holxbeef breed crossbred bulls. The data collected from slaughterhouses included observations of 87323 purebred Hol, 783

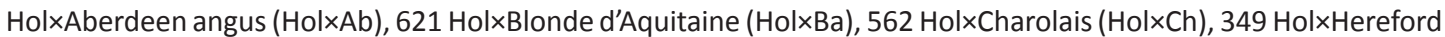

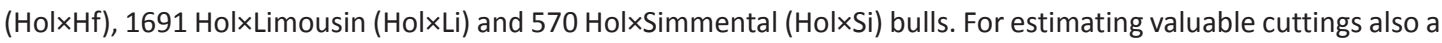
separate dataset was collected and included observations of 8806 purebred $\mathrm{Hol}, 57 \mathrm{Hol} \times \mathrm{Ab}, 29 \mathrm{Hol} \times \mathrm{Ba}, 22 \mathrm{Hol} \times \mathrm{Ch}$, $15 \mathrm{Hol} \times \mathrm{Hf}, 111 \mathrm{Hol} \times \mathrm{Li}$ and $58 \mathrm{Hol} \times \mathrm{Si}$ bulls. Crossbreeding Hol cows with late maturing breeds (Ba, Ch, Li, Si) had favorable effects on carcass gain, conformation and proportion of high value joints of the progeny when compared to purebred Hol bulls. No advantages in proportion of valuable cuttings seemed to be obtained by crossbreeding with $\mathrm{Ab}$ or $\mathrm{Hf}$ breeds, while the improvements in gain and conformation were intermediate compared to the late maturing crossbreds.
\end{abstract}

Key words: beef production, breeds, bulls, carcass characteristics, crossbreeding

\section{Introduction}

Traditionally the majority of beef in Finland has been produced by dairy breeds, and Finnish Ayrshire (Ay) and Holstein-Friesian ( $\mathrm{Hol}$ ) are the two most frequently used breeds. However, the decrease in the number of dairy cows has diminished the supply of calves for beef production originating from dairy herds (Karhula and Kässi 2010). Because the supply of domestic beef has been decreasing, there is nowadays a clear discrepancy between the demand for and supply of domestic beef. Consequently, slaughterhouse pricing favours heavy carcasses and the average carcass weights of slaughtered animals have clearly increased during recent years (Karhula and Kässi 2010). However, the current situation is complicated because fatness generally increases with higher carcass weight (Keane and Allen 1998) and, on the other hand, market demand in Scandinavia concerning carcass fat is different from those beef markets where marbled beef is favoured (Herva et al. 2011). Consumers generally favour low-fat products in Finland, and the beef industry has stated that optimally two thirds of the carcasses would have a EUROP fat score of 2 and one third a EUROP fat score of 3 (Herva et al. 2011). Lean carcasses are favoured in setting prices. There are penalties for carcasses under $320 \mathrm{~kg}$ with fat scores 3-5 and for carcasses over $320 \mathrm{~kg}$ with fat scores 4-5.

One possible approach for current situation could be crossbreeding dairy cows and beef-breed bulls. Currently beef breed semen is used only in $6 \%$ of the dairy cow inseminations in Finland. There is a clear possibility to increase usage of beef breed semen for crossbreeding in dairy cows. Crossbreeding has improved carcass production compared to pure dairy breeds in several experiments during many decades (e.g. Andersen et al. 1976, Kempster et al. 1982, More O'Ferrall and Keane 1990, Aass and Vangen 1998, Keane and Allen 2002). Generally, proportions of hind quarter and/or proportions of hind quarter lean or muscle tissue are higher for beef crosses than for purebred Friesians so crossbreds have produced more valuable carcasses (Kempster et al. 1982, Keane et al. 1989, Keane 1994). However, the number of experimental animals is often limited when growth and carcass characteristics of different breed groups are compared (usually not more than dozens of animals per breed group). Consequently, there is a concern about the representativeness of the experimental animals compared with other animals from the same breed groups, i.e. whether they cover the whole variation in their respective populations. In addition, breed comparisons are mainly relevant for their specific production conditions and genetic level. Therefore, the main objective of the present research based on a large dataset collected from Finnish slaughterhouses was to study the potential for improvement of growth and carcass characteristics through Holstein-Friesian $\times$ beef breed crossbreeding compared to purebred Hol bulls. The second objective was to evaluate carcass traits (conformation, fat score) in relation to carcass weight in different breed groups. It was hypothesized that the use of beef breed crossbreeding improves carcass production compared to purebred Hol bulls. Furthermore, it was hypothesized that production traits improve more by using late maturing (Continental) beef breeds compared to early maturing (British) breeds. 


\section{Materials and methods \\ Dataset - complete slaughter data}

Dataset used in the present study was collected from four Finnish slaughterhouses (A-Tuottajat Ltd., P.O. Box 908, FI-60061 Atria, Finland; HK-Agri Ltd., P.O. Box 50, FI-20521 Turku, Finland; Saarioinen Lihanjalostus Ltd., P.O. Box 108, FI-33101 Tampere, Finland, and Snellman Lihanjalostus Ltd., Kuusisaarentie 1, FI-68600 Pietarsaari, Finland). These slaughterhouses are the major meat companies in Finland, which, as a part of their business operations, transfer calves from dairy farms, or suckler cow herds, to co-operating farms for fattening, and slaughter the animals. A raw slaughter data for each animal included individual animal identification number on ear tag, date of birth, date of slaughter, sex, carcass weight, carcass conformation score and carcass fat score. Identities of breeds (dam and sire breed) were collected from the National Animal Identification Register for Cattle (ProAgria Agricultural Data Processing Centre, P.O. Box 25, FI-01301 Vantaa, Finland). Slaughtering data and identities of breeds for individual animals were linked through individual animal identification numbers. All purebred Hol and Holxbeefbreed crossbred bulls slaughtered by above-mentioned slaughterhouses in 2009-2011 were selected for the study but the animals slaughtered under 365 or above 730 days of age were excluded.

After slaughter the carcasses were weighed hot in all of the slaughterhouses. The cold carcass weight was estimated as 0.98 of the hot carcass weight. The carcasses were classified for conformation and fatness using the EUROP quality classification (EC 2006). For conformation, development of carcass profiles, in particular the essential parts (round, back, shoulder), was taken into consideration according to the EUROP classification (E: excellent, U: very good, R: good, O: fair, P: poor), and for fat cover, the amount of fat on the outside of the carcass and in the thoracic cavity was taken into account using a classification range from 1 to 5 (1: low, 2: slight, 3: average, 4: high, 5: very high). Each level of the conformation scale was subdivided into three sub-classes (e.g. O+, O, O-) to produce a transformed scale ranging from 1 to 15 , with 15 being the best conformation.

Birth weight assumptions used in calculations were $40 \mathrm{~kg}$ live weight and $16 \mathrm{~kg}$ carcass weight for bull calves, since the same values were used by A-Tuottajat Ltd. in daily extension work (Herva et al. 2009, 2011). An estimated daily carcass gain was calculated by subtracting $16 \mathrm{~kg}$ birth carcass weight from the reported slaughter weight and dividing the result by age at slaughter. The complete final slaughter data comprised 91899 slaughtered bulls; the average slaughter age was 587 days and the mean carcass weight $335 \mathrm{~kg}$ (Table 1). The average estimated daily carcass gain was $545 \mathrm{~g} \mathrm{~d}^{-1}$, the EUROP conformation score 4.3 and the carcass fat score 2.4.

Table 1. Description of the experimental data.

\begin{tabular}{|c|c|c|c|c|c|}
\hline Variable & $n$ & Mean & $\mathrm{SD}^{\mathrm{a}}$ & $q_{0.05}{ }^{b}$ & $\mathrm{q}_{0.95}{ }^{\mathrm{c}}$ \\
\hline \multicolumn{6}{|c|}{ Dataset, complete slaughter data } \\
\hline Age at slaughter, $\mathrm{d}$ & 91899 & 587 & 62.8 & 484 & 697 \\
\hline Carcass gain, $\mathrm{g} \mathrm{d}^{-1}$ & 91899 & 545 & 78.8 & 411 & 667 \\
\hline Carcass weight, kg & 91899 & 335 & 49.1 & 250 & 410 \\
\hline Conformation score $^{d}$ & 91710 & 4.3 & 1.11 & 3 & 6 \\
\hline Fat score ${ }^{\mathrm{e}}$ & 91885 & 2.4 & 0.66 & 1 & 3 \\
\hline \multicolumn{6}{|c|}{ Dataset, commercial cutting } \\
\hline Carcass weight, kg & 9098 & 322 & 45.7 & 245 & 392 \\
\hline Conformation score $^{d}$ & 9098 & 4.2 & 0.90 & 3 & 6 \\
\hline Fat score ${ }^{\mathrm{e}}$ & 9098 & 2.4 & 0.65 & 2 & 3 \\
\hline \multicolumn{6}{|l|}{ From yield, \% } \\
\hline Subcutaneous fat & 9098 & 4.7 & 1.44 & 2.6 & 7.3 \\
\hline Loin $^{f}$ & 8682 & 3.7 & 0.34 & 3.2 & 4.2 \\
\hline Tender loin $\mathrm{g}$ & 8694 & 1.4 & 0.12 & 1.2 & 1.6 \\
\hline Inside round ${ }^{h}$ & 8863 & 3.8 & 0.35 & 3.3 & 4.4 \\
\hline Outside round ${ }^{\mathrm{i}}$ & 8892 & 5.8 & 0.59 & 4.9 & 6.6 \\
\hline Corner round ${ }^{j}$ & 8880 & 3.6 & 0.28 & 3.2 & 4.0 \\
\hline Roast beef k & 8925 & 1.8 & 0.18 & 1.5 & 2.1 \\
\hline
\end{tabular}

${ }^{a}$ Standard deviation. ${ }^{\mathrm{b}} 0.05$-quantile (approximately $5 \%$ of the data has a value less than the 0.05 -quantile). ${ }^{\mathrm{c}} 0.95$-quantile (approximately $95 \%$ of the data has a value less than the 0.95 -quantile). ${ }^{d}$ Conformation: $\left(1=\right.$ poorest, $15=$ excellent). ${ }^{\text {e }}$ Fat cover: $(1=$ leanest, $5=$ fattest). ${ }^{\mathrm{f}}$ Musculus longissimus. ${ }^{\mathrm{g}}$ Musculus psoas major. ${ }^{\mathrm{h}}$ Musculus semimembranosus. ${ }^{i}$ Musculus semitendinosus. ${ }^{\mathrm{j}}$ Musculus quadriceps femoris.

${ }^{k}$ Musculus gluteus medius. 


\section{Dataset - commercial cutting}

For estimating valuable cuttings for studied breed groups a separate dataset was collected in 2010-2011 from Snellman Lihanjalostus Ltd. In addition to above-mentioned variables this dataset included also information of commercial cuttings. Each carcass was cut into valuable cuts (outside round, Musculus semitendinosus; inside round, Musculus semimembranosus; corner round, Musculus quadriceps femoris; roast beef, Musculus gluteus medius; tenderloin, Musculus psoas major, and loin, Musculus longissimus) and subcutaneous fat as described by Manninen et al. (2011). All these cuttings were weighed automatically in line and their yields were expressed as percentages of the carcass cold weight ( $0.98 \times$ carcass hot weight, 50 min post mortem). This dataset comprised 9098 slaughtered bulls (Table 1). The mean carcass weight was $4 \%$ lower than that in the complete slaughter data but the average conformation and fat scores were almost the same in both datasets.

\section{Statistical methods}

The results are shown as least squares means. The normality of residuals and the homogeneity of variances were checked using graphical methods: box-plots and scatter plots of residuals and fitted values. The data were subjected the analysis of variance using the SAS Mixed procedure (version 9.2, SAS Institute Inc., Cary, NC). Differences between the breeds were compared using Dunnett's test so that purebred Hol was used as a control breed.

\section{Results}

The complete slaughter data included 87323 purebred Hol bulls (Table 2). The most popular beef breed sires were Limousin (Li, 1691 observations), Aberdeen angus (Ab, 783) and Blonde d'Aquitaine (Ba, 621), while Simmental (Si, 570), Charolais (Ch, 562) and Hereford (Hf, 349) were used less. The average slaughter age for purebred Hol bulls was 587 days, and there were no remarkable differences in the average slaughter ages among breed groups. However, the Ch bulls were 12 days younger $(p<0.001)$ than the Hol bulls.

All crossbred groups differed significantly $(p<0.001)$ from Hol bulls in both carcass weight and carcass gain (Table 2). The estimated average daily carcass gain of the Hol bulls was $542 \mathrm{~g} \mathrm{~d}^{-1}$, and it improved by $7,16,20,10,13$ and

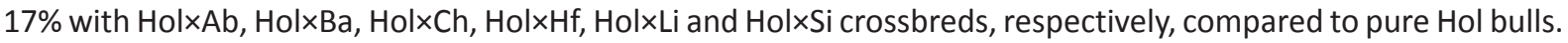
The EUROP conformation score of the Hol bulls was 4.1, and improved most (71-78\%) by using Ba, Li and Ch sires $(p<0.001)$. Hol $\times \mathrm{Ab}$ and Hol $\times \mathrm{Hf}$ crossbreds produced $41 \%$ and Hol $\times \mathrm{Si}$ crossbreds $54 \%$ better conformed carcasses compared to purebred Hol bulls $(p<0.001)$. The carcass fat score of the Hol bulls (2.4) was $14 \%$ higher than that of the Hol $\times \mathrm{Ba}$ bulls $(p<0.001)$. With Hol $\times \mathrm{Ab}, \mathrm{Hol} \times \mathrm{Ch}, \mathrm{Hol} \times \mathrm{Hf}$, Hol $\times \mathrm{Li}$ and Hol $\times \mathrm{Si}$ crossbreds the carcass fat score was $25,4,33,4$ and $13 \%$ higher compared to purebred Hol bulls, respectively $(p<0.001)$.

Dataset from commercial cuttings included 8806 purebred Hol bulls but the amount of the crossbreds was limited (15-111 bulls/breed group) (Table 2). The carcass weights were somewhat lower than those in the complete slaughter data. Breed group had clear effects on the yield (\%) of valuable cuts. The yields of loin, tenderloin, inside round, outside round, corner round and roast beef were higher with $\mathrm{Hol} \times \mathrm{Ba}$ and HolxLi bulls than with $\mathrm{Hol}$ bulls (Table 2). Additionally, the yields of loin, tenderloin, outside round and roast beef were higher with $\mathrm{Hol} \times \mathrm{Si}$ bulls than with Hol bulls. However, the yield of corner round was $3 \%$ lower with HolxSi bulls than with Hol bulls $(p<0.001)$. With Hol $\times$ Ch bulls the yields of loin $(p<0.001)$, outside round $(p<0.001)$ and roast beef $(p<0.01)$ were higher compared to purebred Hol bulls. Furthermore, the yield of corner round was $6 \%$ higher with purebred Hol bulls compared to Hol $\times$ Ab bulls $(p<0.001)$. The yield of subcutaneous fat was significantly lower in the Hol bulls than in the Hol $\times \mathrm{Ab}$, Hol $\times \mathrm{Hf}$ and Hol $\times \mathrm{Si}$ bulls. On the other hand, the yield of subcutaneous fat was $57 \%$ higher with purebred Hol bulls compared to HolxBa bulls $(p<0.001)$.

Average carcass weights in different EUROP fat score classes and the incidence of different fat scores in breed groups are presented in Table 3. The most common class for $\mathrm{Hol}, \mathrm{Hol} \times \mathrm{Ba}, \mathrm{Hol} \times \mathrm{Ch}$ and $\mathrm{Hol} \times \mathrm{Li}$ bulls was fat score 2, including 54, 69, 47 and $45 \%$ of all observations within breed group, respectively. For $\mathrm{Hol} \times \mathrm{Ab}, \mathrm{Hol} \times \mathrm{Hf}$ and $\mathrm{Hol} \times \mathrm{Si}$ bulls fat score 3 incidence was greater than score 2, being 48, 46 and 50\%, respectively. Considering fat score 4, it is noticed that 25 and $28 \%$ of Hol $\times \mathrm{Ab}$ and HolxHf carcasses were placed to this category. For other breed groups less than $10 \%$ of carcasses ranked to class 4 . In addition, 3 and $6 \%$ of HolxAb and HolxHf carcasses, respectively, and less than $1 \%$ carcasses for other breed groups were placed to fat score 5 . In general, the average carcass weight of the crossbred bulls in different fat score classes was higher than that of the purebred Hol bulls (Table 3). For example, in fat score 3 the average carcass weights were 2, 13, 15, 3, 10 and 14\% higher with $\mathrm{Hol} \times \mathrm{Ab}, \mathrm{Hol} \times \mathrm{Ba}$, $\mathrm{Hol} \times \mathrm{Ch}, \mathrm{Hol} \times \mathrm{Hf}$, HolxLi and HolxSi crossbreds, respectively, compared to pure Hol bulls. 


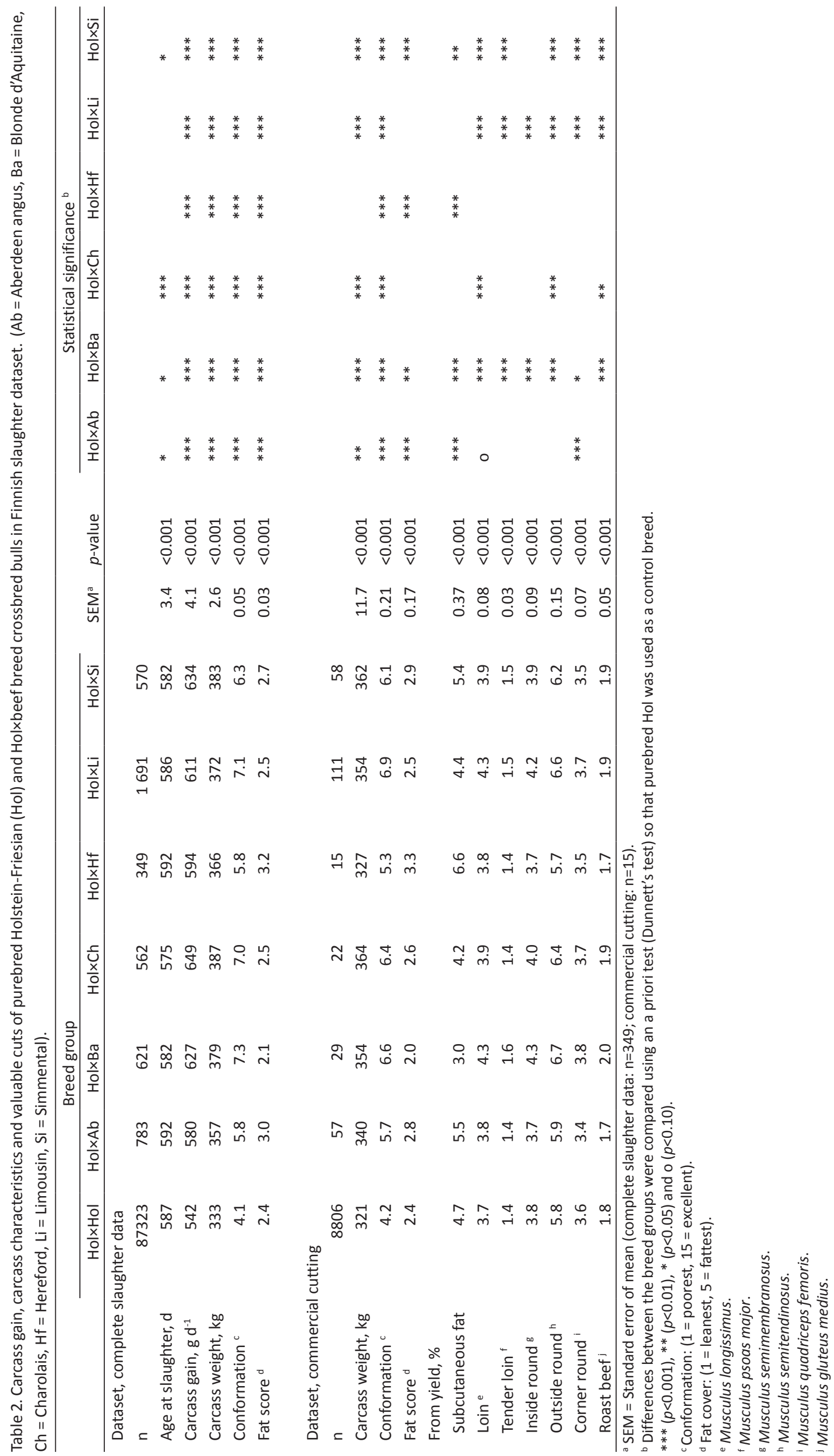




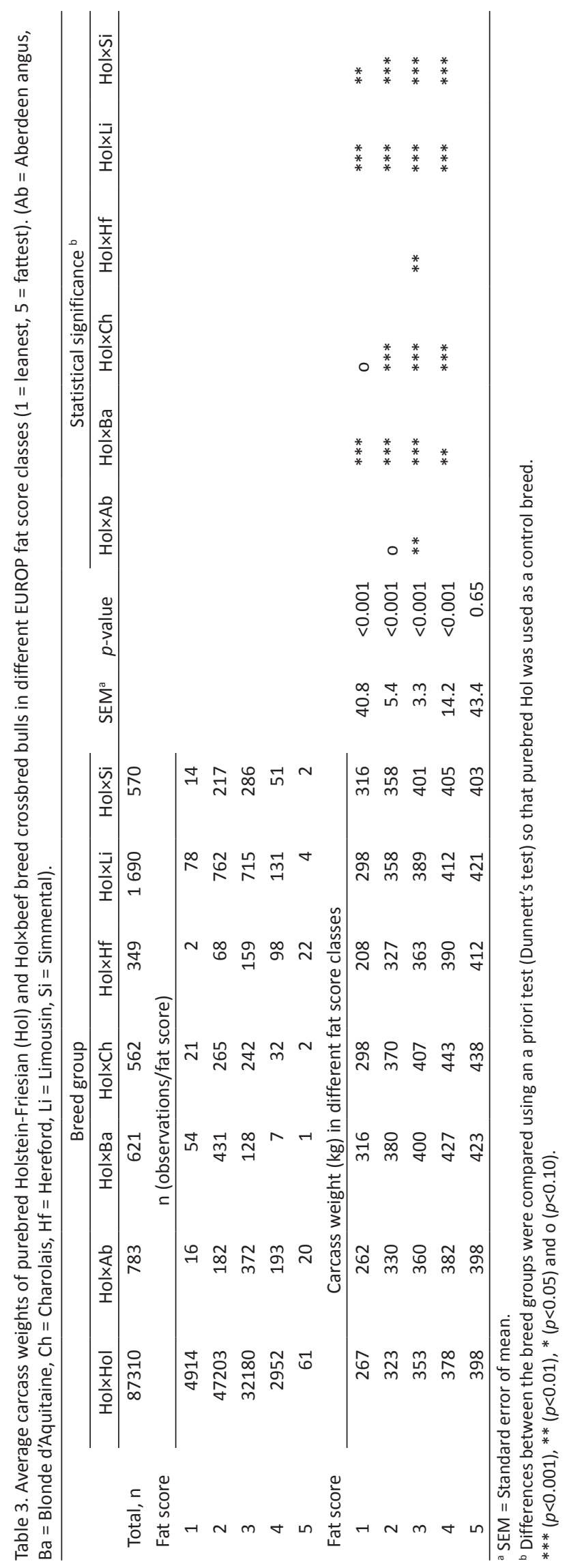



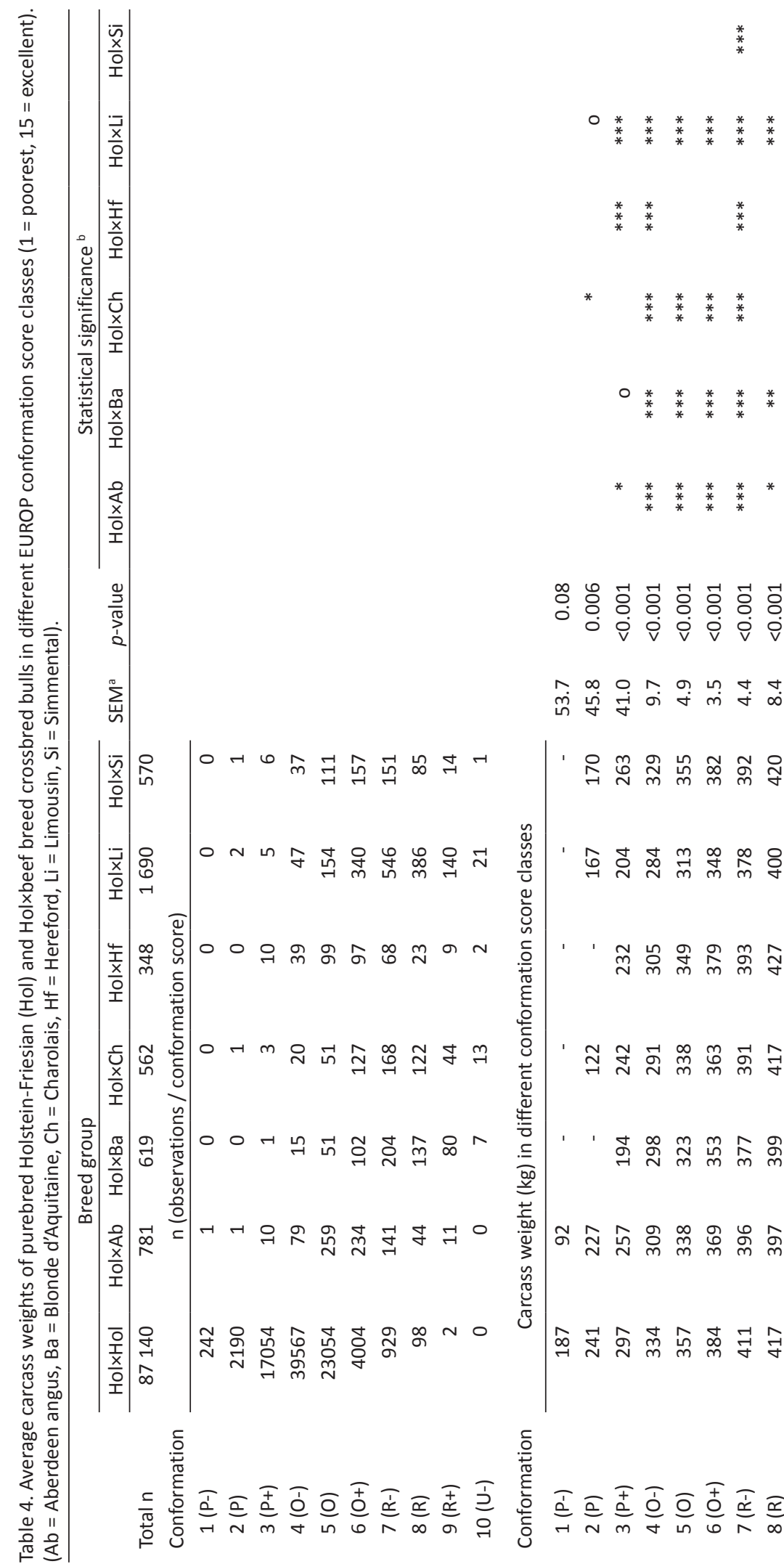

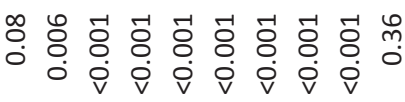

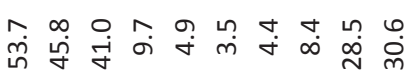

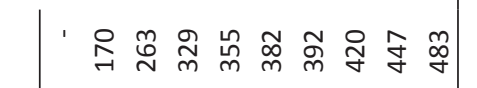

兽

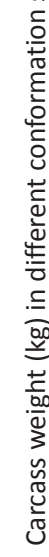

\%

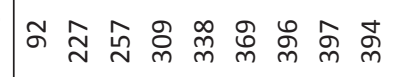

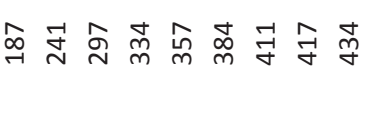

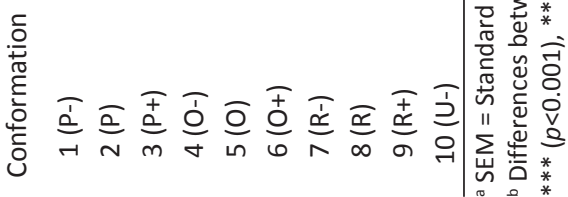


For purebred Hol bulls majority of carcasses (91\%) were placed to conformation scores $3(\mathrm{P}+)$ to $5(\mathrm{O})$, and the most common conformation class was $\mathrm{O}-(45 \%$ of all observations) (Table 4). Considering Hol $\times \mathrm{Ab}, \mathrm{Hol} \times \mathrm{Hf}$ and $\mathrm{Hol} \times \mathrm{Si}$

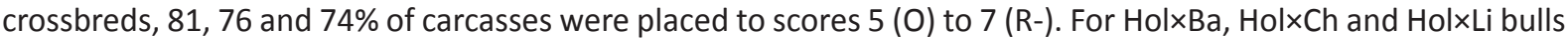
a notable (more than $20 \%$ ) amount of carcasses ranked to class 8 (R). In total, only 94 carcasses were classified to scores $11(\mathrm{U})$ to $15(\mathrm{E}+)$, and these observations are not shown in Table 4. Considering the most common conformation classes (4-7), the average carcass weights of crossbred bulls were lower compared to purebred Hol bulls. For example, in conformation score 7 (R-) the average carcass weights were 4, 8, 5, 4, 8 and 5\% lower with Hol $\times A b$, $\mathrm{Hol} \times \mathrm{Ba}$, Hol $\times \mathrm{Ch}$, Hol $\times \mathrm{Hf}$, Hol $\times \mathrm{Li}$ and Hol $\times \mathrm{Si}$ crossbreds, respectively, compared to pure Hol bulls. In other words, the crossbred bulls were classified better than the Hol bulls in the same carcass weight.

\section{Discussion}

Lifetime daily carcass gain (545 $\mathrm{g} \mathrm{d}^{-1}$ on average) observed in the present data was in line with the observations reported by Herva et al. (2009) (538 g d $\mathrm{g}^{-1}$ ) based on results of 55375 bull calves delivered by Atria Ltd. in 2003. Compared to the recent Finnish experimental data sets for dairy bulls with typical Finnish grass silage-based diets (e.g. Huuskonen et al. 2007, 2008, 2011, Huuskonen 2009, 2011, Huuskonen and Joki-Tokola 2010), the average lifetime carcass gain was approximately $10 \%$ lower in the present field data. This difference probably illustrates variable feeding regimes and management factors at farm level compared to the controlled experimental environments. Typically all bull calves transferred from dairy farms are housed and fed consistently in finishing farms i.e. different methods are not used for pure dairy breeds and dairyxbeef crossbred bulls within a finishing farm. Therefore it can be assumed that the results of the present data represent well the differences between the breed groups in Finnish cattle population.

The higher growth capacity of the dairyxlate maturing beef breed crosses compared to the pure dairy breeds has been demonstrated in numerous studies (e.g. Andersen et al. 1977, More O'Ferrall and Keane 1990). However, it can be inferred from data compiled by Kempster and Southgate (1984) and Keane et al. (1989) that there was little difference in growth rate between Friesians and Limousin crosses in some trials. Also Andersen et al. (1977) found that Limousin cross young bulls from dairy cows had lower daily live weight gains than and similar daily carcass gains as Danish Red and White young bulls. Southgate et al. (1988) reported similar live growth rates for Friesian, Friesian $\times$ Hereford and Friesian $\times$ Limousin steers in a 16-month beef system but in a 24-month system the Limousin crosses were superior. In many early mentioned British and Irish studies with the progeny of Friesian dairy cows, purebred Friesians have performed better in relation to beef breed crosses than in the present experiment. This indicates weak growth properties in current Finnish Holstein-Friesian population.

The fact that there are differences between breed types in conformation and fat scores has been well established previously in experimental data sets (Kempster et al. 1982, More O'Ferrall and Keane 1990, Keane and Allen 2002), and this was also the case in the present large field data. For example, the superiority of the Hol $\times \mathrm{Li}$ and $\mathrm{Hol} \times \mathrm{Ba}$ crossbred bulls for carcass conformation compared to purebred Hol bulls corresponded to the results reported by Keane et al. (1989) with Friesian, Friesian $\times$ Limousin and Friesian $\times$ Blonde d'Aquitaine steers. Furthermore, Keane and More O'Ferrall (1992) observed that Friesian×Hereford and Friesian×Simmental steers conformed 36 and $40 \%$ better than purebred Friesians, respectively.

Aass and Vangen (1998) suggested that commercial conformation grading is in general an imprecise method for evaluation of carcass composition. Also in the present study the differences in conformation score suggested a superior muscling of the HolxAb and HolxHf crosses compared to pure Hol bulls. However, in terms of valuable cuts there were only limited differences between Hol, HolxAb and HolxHf bulls. Instead, Holxlate maturing breed bulls had higher proportions of many high value joints (rounds, loins) compared to purebred Hol bulls. Other studies have also shown that the late maturing breed type cattle have higher proportions of high value joints than early maturing breed crosses or pure dairy breeds (Andersen et al. 1977, Keane et al. 1989, 1990, Keane and More O'Ferrall 1992). In general, carcass conformation and fat scores have explained moderate to high proportions of the variation ( $R^{2}$ ranged from 0.47 to 0.70 ) in carcass meat yield (Perry et al. 1993, Drennan et al. 2008, Conroy et al. 2009, 2010). Craigie et al. (2012) reported how point changes in the EUROP grid relate to changes in the yield of lean meat in the whole beef carcass as well as in to the yield of high value cuts relative to carcass weight. Studies summarized by Craigie et al. (2012) indicated that the percentage of variation ( $R^{2}$ range $0.55-0.75$ ) in carcass lean meat yield explained by the EUROP grid was much greater using the entire carcass than using high-value cuts only ( $R^{2}$ range $\left.0.28-0.57\right)$. While these high-value cuts are a small percentage of the carcass lean meat yield, they account for a large proportion of carcass value. Craigie et al. (2012) concluded that there is a clear need for an accurate commercial measurement or prediction methods for true value of the carcasses which is supported also by the present data. 
Although measures of carcass fatness generally increase with increasing carcass weight (Keane and Allen 1998), the carcass fat score of the Hol×Ba bulls was lower than that of the Hol bulls at a constant age in the present study. This disagrees with findings by Aass and Vangen (1998) who reported that sire breed differences in carcass fatness traits became insignificant when comparisons were made at a constant age instead of weight. However, the carcass weights were considerably higher in the present study compared to those reported by Aass and Vangen (1998). In accordance with our results, Wheeler et al. (2005) observed that Hf-sired steers were fatter than Chsired steers when slaughtered at constant age. Similarly, Schenkel et al. (2004) reported with purebred beef bulls that Blonde d'Aquitaine bulls showed the least back fat thickness, followed by Limousin, Charolais and Simmental when breed differences for growth and body composition traits were studied in Ontario bull test stations from 1991 to 2000. In that case, the Hf bulls had the highest level and the Ab bulls the second highest level of back fat thickness (Schenkel et al. 2004). Also Bartoň et al. (2006) concluded that, in general, the animals of earlier maturing breeds $(\mathrm{Hf}, \mathrm{Ab})$ produced relatively more fat than later maturing $(\mathrm{Ch}, \mathrm{Si})$ in spite of the fact that they were slaughtered at a significantly lower live weight. This statement is supported by the present data with crossbred bulls.

The decrease in the number of dairy cows has reduced the number of dairy bred calves available for beef production in Finland and while the beef cow herd has increased (Karhula and Kässi 2010), it is not sufficient to offset the fall in the dairy cow number. Consequently, if beef output is to be maintained, carcass weights must increase. However, increasing carcass weight with the present breed distribution is not desirable, as beef carcasses are already adequately fat or over-fat at existing carcass weights (Herva et al. 2011). The way by which carcass weight can increase without a subsequent increase in fatness is through a change in breed distribution. According to the present data the $\mathrm{Hol}, \mathrm{Hol} \times \mathrm{Ab}$, and $\mathrm{Hol} \times \mathrm{Hf}$ bulls would obtain carcass fat class 3 at carcass weights of ca. 350-360 $\mathrm{kg}$ but Holxlate maturing crossbreds at carcass weights of ca. 390-400 kg. Thus the use of late maturing rather than early maturing bulls on Hol dairy cows would permit carcass weight of the progeny to increase $10-15 \%$ without an increase in carcass fatness. Alternatively, in recognition of the growing consumer demand for beef with less fat, the fat content of Holxlate maturing carcasses would be lower than that of purebred Hol or Holxearly maturing carcasses of similar weight. However, the decision to opt for a breed when crossbreeding dairy cattle depends not only on the growth performance and carcass characteristics of the calf but also on the aspects affecting the dairy production, such as gestation length, calving difficulty or occurrence of stillbirth (Fouz et al. 2013). In the present study we didn't have possibility to evaluate those aspects affecting the dairy production but several published articles are available (e.g. Nadarajah et al. 1989, Olson et al. 2009, Fouz et al. 2013). Based on Finnish statistics (Ilola 2012) the proportion of stillbirths was 5.2\% for purebred dairy calves (Hol and Ayrshire breeds, on average) in Finnish dairy farms during 1.8.2011-31.7.2012. For Ab, Ba, Ch, Hf, Li and Si crossbreds proportions of stillbirth were 4.4, 4.4, 4.9, 5.1, 5.1 and $4.0 \%$, respectively.

\section{Conclusions}

The large dataset collected in this study describes well the growth and carcass traits of slaughtered bulls in Finnish Holstein-Friesian population. Improvements in beef production traits obtained by crossbreeding Holstein-Friesian dairy cows with beef breed sires are highly dependent of the choice of sire breed. Crossbreeding Hol cows with late maturing beef breeds ( $\mathrm{Ba}, \mathrm{Ch}, \mathrm{Li}, \mathrm{Si}$ ) had favorable effects both on daily carcass gain and carcass quality traits (conformation, proportion of high value joints) of the progeny when compared to purebred Hol bulls. The effects of crossbreeding Hol cows with Ab or $\mathrm{Hf}$ sires were variable. No advantages in proportion of high value joints seemed to be obtained by crossbreeding Hol cows with these early maturing breeds, while the improvements in daily carcass gain and carcass conformation score were intermediate compared to the late maturing crossbreds. Crossbreeding, especially with late maturing bulls, largely improves carcass production compared to purebred Hol bulls.

\section{Acknowledgements}

This study was a part of the co-operation between MTT Agrifood Research Finland and Savonia University of Applied Sciences to find ways to develop and improve milk and beef production in Finland. The study was partially funded by the Centre for Economic Development, Transport and the Environment for North Savo, A-Tuottajat Ltd., HK-Agri Ltd., Saarioinen Lihanjalostus Ltd., Snellman Lihanjalostus Ltd. and Valio Ltd. We would like to thank Ms. Maarit Hyrkäs for the data processing and statistical analyses. We wish to express our gratitude to Prof. Marketta Rinne for useful comments on the manuscript. 


\section{References}

Aass, L. \& Vangen, O. 1998. Carcass and meat quality characteristics of young bulls of Norwegian cattle and crossbreds with Angus, Hereford and Charolais. Acta Agriculturae Scandinavica, Section A, Animal Science 48: 65-75.

Andersen, B. B., Liboriussen, T., Kousgaard, K. \& Buchter, L 1977. Crossbreeding experiment with beef and dual-purpose sire breeds on Danish dairy cows. III. Daily gain, feed conversion and carcass quality of intensively fed young bulls. Livestock Production Science 4: 19-29.

Andersen, B. B, Liboriussen, T., Thysen, I., Kousgaard, K. \& Buchter, L. 1976. Crossbreeding experiment with beef and dual-purpose sire breeds on Danish dairy cows. Livestock Production Science 3: 227-238.

Bartoň, L., Řehák, D., Teslík, V., Bureš, D. \& Zahrádková, R. 2006. Effect of breed on growth performance and carcass composition of Aberdeen Angus, Charolais, Hereford and Simmental bulls. Czech Journal of Animal Science 51: 47-53.

Conroy, S.B., Drennan, M.J., Kenny, D.A. \& McGee, M. 2009. The relationship of live animal muscular and skeletal scores, ultrasound measurements and carcass classification scores with carcass composition and value in steers. Animal 3: 1613-1624.

Conroy, S.B., Drennan, M.J., Kenny, D.A. \& McGee, M. 2010. The relationship of various muscular and skeletal scores and ultrasound measurements in the live animal, and carcass classification scores with carcass composition and value of bulls. Livestock Science 127: 11-21.

Craigie, C.R., Navajas, E.A., Purchas, R.W., Maltin, C.A., Bünger, L., Hoskin, S.O., Ross, D.W., Morris, S.T. \& Roehe, R. 2012. A review of the development and use of video image analysis (VIA) for beef carcass evaluation as an alternative to the current EUROP system and other subjective systems. Meat Science 92: 307-318.

Drennan, M.J., McGee, M. \& Keane, M.G. 2008. The value of muscular and skeletal scores in the live animal and carcass classification scores as indicators of carcass composition in cattle. Animal 2: 752-760.

EC 2006. Council Regulation (EC) No 1183/2006 of 24 July 2006 concerning the Community scale for the classification of carcasses of adult bovine animals. The Official Journal of the European Union L, 214: 1-6.

Fouz, R., Gandoy, F., Sanjuán, M.L., Yus, E. \& Diéguez, F.J. 2013. The use of crossbreeding with beef bulls in dairy herds: effects on calving difficulty and gestation length. Animal 7: 211-215.

Herva, T., Huuskonen, A., Virtala, A.-M. \& Peltoniemi, O. 2011. On-farm welfare and carcass fat score of bulls at slaughter. Livestock Science 138: 159-166.

Herva, T., Virtala, A-M., Huuskonen, A., Saatkamp, H. W. \& Peltoniemi, O. 2009. On-farm welfare and estimated daily carcass gain of slaughtered bulls. Acta Agriculturae Scandinavica, Section A, Animal Science 59: 104-120.

Huuskonen, A. 2009. The effect of cereal type (barley versus oats) and rapeseed meal supplementation on the performance of growing and finishing dairy bulls offered grass silage-based diets. Livestock Science 122: 53-62.

Huuskonen, A. 2011. Effects of barley grain compared to commercial concentrate or rapeseed meal supplementation on performance of growing dairy bulls offered grass silage-based diet. Agricultural and Food Science 20: 191-205.

Huuskonen, A., Huumonen, M., Joki-Tokola, E. \& Tuomisto, L. 2011. Effects of different liquid feeding strategies during the preweaning period on the performance and carcass characteristics of dairy bull calves. Acta Agriculturae Scandinavica, Section A, Animal Science 61: 187-195.

Huuskonen, A. \& Joki-Tokola, E. 2010. Performance of growing dairy bulls offered diets based on silages made of whole-crop barley, whole-crop wheat, hairy vetch and grass. Agricultural and Food Science 19: 116-126.

Huuskonen, A., Khalili, H. \& Joki-Tokola, E. 2007. Effects of three different concentrate proportions and rapeseed meal supplement to grass silage on animal performance of dairy-breed bulls with TMR feeding. Livestock Science 110: 154-165.

Huuskonen, A., Khalili, H. \& Joki-Tokola, E. 2008. Need for protein supplementation in the diet of growing dairy bulls fed total mixed ration based on moderate digestible grass silage and barley. Agricultural and Food Science 17: 109-120.

Ilola, M. 2012. Lehmävasikoista lisää lihaa. Nauta 42 (4): 27-28. (in Finnish).

Karhula, T. \& Kässi, P. 2010. Lihanautatilojen taloudellinen tilanne Suomessa ja vertailumaissa. In: Arto Huuskonen (ed.). Kehitystä naudanlihantuotantoon I. [Towards More Efficient Beef Production I]. Tampereen yliopistopaino Juvenes Print Ltd., Tampere, Finland. p. 9-34. (in Finnish with English Abstract).

Keane, M.G. 1994. Productivity and carcass composition of Friesian, Meuse-Rhine-Issel (MRI) $\times$ Friesian and Belgian Blue $\times$ Friesian steers. Animal Production 59: 197-208.

Keane, M.G. \& Allen, P. 1998. Effects of production system intensity on performance, carcass composition and meat quality of beef cattle. Livestock Production Science 56: 203-214.

Keane, M.G. \& Allen, P. 2002. A comparison of Friesian-Holstein, Piemontese $\times$ Friesian-Holstein and Romagnola $\times$ Friesian-Holstein steers for beef production and carcass traits. Livestock Production Science 78: 143-158.

Keane, M.G. \& More O'Ferrall, G.J. 1992. Comparison of Friesian, Canadian Hereford $\times$ Friesian and Simmental $\times$ Friesian steers for growth and carcass composition. Animal Production 55: 377-387.

Keane, M.G., More O’Ferrall, G.J. \& Connolly, J. 1989. Growth and carcass composition of Friesian, Limousin × Friesian and Blonde d'Aquitaine $\times$ Friesian steers. Animal Production 48: 353-365.

Keane, M.G., More O'Ferrall, G.J., Connolly, J. \& Allen, P. 1990. Carcass composition of serially slaughtered Friesian, Hereford $x$ Friesian and Charolais $\times$ Friesian steers finished on two dietary energy levels. Animal Production 50: 231-243. 
Kempster, A.J., Cook, G.L. \& Southgate, J.R. 1982. A comparison of the progeny of British Friesian dams and different sire breeds in 16- and 24-month beef production systems. 2. Carcass characteristics and rate and efficiency of meat gain. Animal Production 34: 167-178.

Kempster, A.J. \& Southgate, J.R. 1984. Beef breed comparisons in the U.K. Livestock Production Science 11: 491-501.

Manninen, M., Honkavaara, M., Jauhiainen, L., Nykänen, A. \& Heikkilä, A.-M. 2011. Effects of grass-red clover silage digestibility and concentrate protein concentration on performance, carcass value, eating quality and economy of finishing Hereford bulls reared in cold conditions. Agricultural and Food Science 20: 151-168.

More O'Ferrall, G.J. \& Keane, M.G. 1990. A comparison for live weight and carcass production of Charolais, Hereford and Friesian steer progeny from Friesian cows finished on two energy levels and serially slaughtered. Animal Production 50: 19-28.

Nadarajah, K., Burnside, E.B. \& Schaeffer, L.R. 1989. Factors affecting gestation length in Ontario Holsteins. Canadian Journal of Animal Science 69: 1083-1086.

Olson, K.M., Cassell, B.G., McAllister, J.A. \& Washburn, S.P. 2009. Dystocia, stillbirth, gestation length, and birth weight in Holstein, Jersey, and reciprocal crosses from a planned experiment. Journal of Dairy Science 92: 6167-6175.

Perry, D, Yeates, A.P. \& McKiernan, W.A. 1993. Meat yield and subjective muscle scores in medium weight steers. Australian Journal of Experimental Agriculture 33: 825-831.

Schenkel, F.S., Miller, S.P. \& Wilton, J.W. 2004. Genetic parameters and breed differences for feed efficiency, growth and body composition traits of young beef bulls. Canadian Journal of Animal Science 84: 177-185.

Southgate, J.R., Cook, G.L. \& Kempster, A.J. 1988. Evaluation of British Friesian, Canadian Holstein and beef breed $\times$ British Friesian steers slaughtered over a commercial range of fatness from 16-month and 24-month beef production systems. 1. Live-weight gain and efficiency of food utilization. Animal Production 46: 353-364.

Wheeler, T.L., Cundiff, L.V., Shackelford, S.D. \& Koohmaraie, M. 2005. Characterization of biological types of cattle (cycle VII): Carcass, yield, and longissimus palatability traits. Journal of Animal Science 83: 196-207. 